\title{
Dian Fossey's Controversial 'Active Conservation' Proves Useful in Increasing Mountain Gorilla Awareness
}

Brandy Rimmer*

MacEwan University, Canada

\begin{abstract}
As a researcher and advocate of the mountain gorilla, Dian Fossey dedicated her life career to understand, protect, and assist the mountain gorilla by bringing awareness to the complexity of this animal and to the habitat needs required to support it. This paper presents the approach that Fossey used to increase the mountain gorilla awareness: 'Active Conservation'.
\end{abstract}

\section{Virunga National Park}

It was Dr. Louis Leakey, renowned archaeologist and anthropologist, who realized that the mountain gorillas were facing the threat of extinction in the very same century that they were discovered (Fossey, 1983). It was for this reason that he hired Dian Fossey to carry out research on the mountain gorillas in the Rwandan mountains. In his life, Louis Leakey put a substantial amount of energy into promoting research on the behaviour of non-human primates. Along with hiring Dian Fossey for studies on gorillas, he had similarly been responsible for Jane Goodall's research on chimpanzees and Birute Galdika's work on orangutans (Hinde, 1978). 
Dian Fossey lived and worked at the Karisoke research Center in Volcanoes National Park (Parc National des Volcans) in Rwanda for a total of 18 years starting in 1967 (the year it was founded). This is where she established a research center funded by the National Geographic Society (NGS). In this location, she took on the role of leading her own anti-poaching patrols and even apprehended poachers. Fossey referred to her work as 'active conservation'. She successfully made the world interested in the plight of the mountain gorillas through films and articles produced for National Geographic. Fossey's life story is filled with hardship, extreme dedication, and possibly a walk on the side of insanity (Cara, 2007). Despite the drastic measures that she took, the overall outcome of her work was in favour of the mountain gorillas' future survival, as well as a step in the right direction in regards to the conservation movement.

In Fossey's first career as an occupational therapist, she used resourceful tactics to remove children from constrained environments, such as taking them to creeks to dig for clay. While in Kentucky she worked with children from the Appalachians and described them as "penned-up wild animals" (Cara, 2007). Early on, it seemed as if Fossey took on the role of a protector and was dedicated to providing freedom to those who struggled for it. Through her actions she displayed how much she valued independence. In her early years, Fossey was dedicated to protecting disabled children, while later on, she switched her focus to protecting the mountain gorillas of the Volcanoes National Park. Although these environments were drastically different physically, both careers involved maintenance, work, play, and recreational occupations, which provided her with feelings of self-reward (Cara, 2007).

\section{The Majestic Mountain Gorilla}

The mountain gorilla subspecies was scientifically recognized and described in 1902 (Fossey, 1983). They are the largest of the great apes and have a range limited to a small lush area in Central Africa (Fossey, 1970). George Schaller's year-long study preceded Fossey's work and was the only research conducted on the mountain gorillas in their natural environment prior to Fossey's 18 years of field work. A mountain gorilla group exhibits extremely cohesive family unity, more so than any other primate group, a fact that impressed Schaller. Adult gorillas will fight to the death defending their families and young, which is why poachers have destroyed whole groups of gorillas when their goal was to capture only the infants for the zoo trade. Fossey believed that no animal was safe in Africa and would protect any that she stumbled upon. She had an extreme softspot when it came to children or animals. From the start, Fossey had tried to evict cattle herders from the park, kidnapping or shooting their livestock. These livestock owners 
would modify the gorilla's habitat in order to increase the available pasture for cattle grazing. This then forced the mountain gorillas higher up in altitude where the land was not conducive to farming and ranching (Cawthon, 2005). Although she felt guilty about harming the animals, they were responsible for destroying gorilla habitat. Poachers in the area would kill gorillas and sell their heads to westerners as trophies, hands as ashtrays, and infant gorillas as zoo animals. An infant gorilla in the zoo trade can earn a poacher up to 86,000 pounds (Mukanjari et al., 2010). As the poaching increased, and two young gorillas were stolen from Fossey's care and sold, her tactics toward anti-poaching became more extreme (Montgomery, 1991).

\section{Active Conservation}

As previously stated, Dian Fossey referred to her extreme tactics as 'active conservation'. This included funding an army of anti-poaching scouts. When Fossey came across poachers, it was said that she would employ methods of torture, burning their possessions and occasionally kidnapping their children (Montgomery, 1991). After her favorite gorilla, Digit, and other familiar gorillas were slain, her anti-poaching war became personal. Not even Jane Goodall, who described Fossey as a good friend, could condone her extreme tactics. Many individuals claim that Fossey was responsible for bringing on her own death as much as the person who wielded the spear that split her skull in 1985 (Montgomery, 1991). She imposed her own laws on a sovereign nation and made enemies of the locals. Dian Fossey did not exhibit the care for the native people that she did for the mountain gorillas. Her attitude toward children and animals was very western in origin. It was in her 'active conservation' that she developed the African philosophy. She used stinging nettles as a method of torture, a concept borrowed from the African tradition. She painted hexes, cast spells, and pronounced curses (Montgomery, 1991). To the Africans, the idea of witchcraft was very real and Fossey used this to her advantage. Not only did she perform witchcraft, but she came to think of herself as a witch. Although it has been suggested that some of her personal accounts have been exaggerated, they are thought to generally encompass a truthful basis. She experienced a great deal of pain and emotional turmoil on her road to improve the lives of her beloved gorillas. Many of her claims, if not reality, may have been a way for her to emotionally enact some of the acts of hatred that she had craved to carry out. She was outraged by the atrocities committed against the mountain gorillas. It was not the Rwandan locals that Fossey angered as a result of her actions, so much as the authorities that she had diverted money away from through her tourist scare tactics. She did not like any intruders in her camp or near the gorillas. In articles and films, she displayed the

Rwandan authorities as incompetent in protecting the mountain gorillas (Montgomery 
1991). For obvious reasons, this did not sit well with Rwandan authorities and they reacted by approaching Fossey with their concerns and options to work out their differences. One of these options involved Fossey leaving the area, possibly returning at a later date. She felt like she did not have time to craft 'resource management plans' or wait for diplomatic solutions to be reached, so she employed her 'active conservation' as it was the only method she felt would be effective in protecting the gorillas (Montgomery, 1991).

In her later years, former students spread rumors of her paranoia, alcoholism and aggressive behaviour toward tourists (Montgomery, 1991). The State Department seemed most anxious to arrange her departure, but tried to work out their differences in a seemingly diplomatic manner (Haye,s 1990). Both the Leaky Foundation and the National Geographic Society threatened to withhold their subsidies and by 1984, National Geographic had completely cut off Fossey's support. She then rallied one last time, using money from the Digit Fund (explained later, under 'Relevant Conservation Societies') and from her book Gorillas in the Mist and significantly increased poacher patrols. A report that she had written from the first quarter of 1984 stated that her patrols had cut 582 traps and spotted 67 poachers (Hayes, 1990). Despite her 'active conservation' philosophy and the fact that she either angered or scared a significant number of people, Dian Fossey spurred great advancements in the area of environmental protection and awareness. The Rwandan government has become supportive of gorilla conservation and has allocated more land around the park for cultivation and expansion (Nielsen \& Spenceley, 2010).

\section{Dian's Contributions}

Fossey wrote that she didn't habituate the gorillas she studied to Africans because she feared that if they got too used to the locals they would face greater danger when poachers approached the gorilla groups. She did, however, mention that conservation ultimately rested in the hands of the Africans. She took great pride in the fact that she was the first person to fully habituate gorillas to the presence of humans (Fossey 1983). This habituation process took nearly three years and involved extreme patience and determination. Fossey spent countless hours in the bush observing the gorillas and recording their behaviours (Krajicek). Her relentless hours eventually paid off and Fossey was able to make the gorillas much more at ease with her presence. Her scientific accounts of the gorillas provided anthropologists and zoologists with the first specific behavioural development and social organization information regarding gorillas in their natural setting. Her work demonstrated the occurrence of infanticide and provided 
important information on reproductive characteristics in the mountain gorillas. Fossey and her co-workers described intergroup transfers and emigration between groups (Douglas, 1985). This work was conducted based on previous questions posed by Schaller. Fossey expanded on and answered many of Schaller's questions while completing her P.h.D. The questions he raised concerned concepts such as immigration and emigration, particularly the movement of females between different groups (Fossey, 2008). She also estimated gorillas' life expectancy to be 60 years, while Schaller had estimated this number to be only 30 years.

To differentiate between the specific groups of gorillas in the area, Fossey allocated a number to each group. From her research, she was able to shed some light on the range of land that the gorillas would utilize, feeding ecology, vocalizations, and infant development (Douglas, 1985). It was in her later years that her focus moved away from studying the gorillas' behaviour and ecology and more toward conserving the species.

In her book Gorillas in the Mist (Fossey, 1983), and the subsequent film based on the book, Fossey described how she manipulated local customs and religion to scare poachers away from her nature preserve. She encouraged locals to think of her as a witch and even painted pictures of herself on the entrances to the gorillas' territory (Fossey, 1983). The message of the film was used to show the selfish desires of zoos and tourism and furthermore the way that these industries exploited animals to make a profit. It was her identification with the gorillas as her animal family that was said to have justified the extreme measures she went to. The film, and resultantly Fossey's methods, have been criticized in some lights but have also been said to have symbolic importance by identifying a newly emerging ideology of animals at the time (Nash \& Sutherland, 1991).

\section{The Ape Ladies}

As women entered the conservation movement, tensions arose between men and women in regard to who was better qualified for the research. Dian Fossey played a large part in conservation during her time. The world of conservation was undoubtedly impacted by this leading female researcher. Fossey challenged the prevailing societal ideas of not only what we think but how we think. This is what helped to teach society to encounter nature as an intimate area that should not be disturbed (Forth, 1994). Fossey's drastic conservation measures definitely made people aware of the lengths that some would go to protect the natural world and the animals in it. Although there may have 
been problems with her ethics, she drew attention to the depleting numbers of the mountain gorillas and overall, helped to further the conservation movement. It was thought that Louis Leakey chose female researchers because he reasoned that they would be seen as less threatening to male primates and would, as a result, show less aggression (Kanner, 2006). He trusted his 'ape ladies' (Fossey, Goodall, and Galdikas) and admired their "patience, persistence, and perception" (Kahn et al., 1993). While Fossey worked with mountain gorillas, Goodall studied chimpanzees, and Galdikas became the foremost authority on orangutans (Dr. Birute Mary Galdikas Biography, 2011). Galdikas has worked tirelessly for close to four decades to save the orangutans and the forests in which they reside. Her major goal became bringing the plight of the orangutans to the attention of the world.

Jane Goodall took a much more level-headed approach to her studies in comparison to Fossey. She was often described as cool and poised and would not raise an unseemly fuss, possibly because the chimpanzees she studied were safe (Montgomery, 1991). Where Fossey excluded the Africans from her studies, Goodall trained the Africans and expected them to succeed her, which was probably a better method in terms of future conservation education.

Fossey felt as if she was forever stuck in Goodall's shadow (Montgomery, 1991). Fossey made significant discoveries, especially regarding reproduction and infanticide, as previously discussed. These discoveries seemed to be outshone by Jane Goodall's work done on chimpanzee hunting and tool use. Her work was more relatable to humans and more anthropomorphic in nature, which was elucidated by the chimps' warfare and cannibalism (Montgomery, 1991). Many individuals, including Jane Goodall and Birute Galdikas, could not understand what possessed Dian Fossey to rise to the extremes that she did in protecting the animals that she studied. Although both Goodall and Galdikas could sympathize with Fossey's devotion to her primate research subjects, they could not condone her behaviour.

\section{Relevant Conservation Societies}

As a result of the death of Digit, Dian Fossey's favorite gorilla, the Digit fund was established in 1978 (Cara, 2007). This fund became a reality as Fossey carried out a series of lectures around the world, concerning the mountain gorillas. It now holds the title of the Dian Fossey Gorilla Fund and is sponsored by the Morris Animal Foundation of Englewood, Colorado. Today, there are daily patrols which monitor the health and safety of the gorillas. These daily patrols are done thanks to the government of Rwanda and the general public contributions, the Digit Fund, the Mountain Gorilla Project, the Fauna 
and Flora Preservation Society of Great Britain, and the World Wide Fund for Nature (Hayes, 1990). Guards remove close to 1,000 snares each year and help to bring poachers to justice (Dian Fossey Gorilla Fund International). Karisoke, supported by the Dian Fossey Gorilla Fund, has established relations with many of the communities surrounding the park. It helps to run many local health and education programs, which includes treating intestinal parasites, providing clean water, and health rehabilitation clinics. It also provides conservation education to schools in the area.

The Virunga National Park (Virunga Massif) is termed a UNESCO (United Nations Educational, Scientific and Cultural Organization) World Heritage Site (Virunga National Park). Although her methods were questionable, Dian Fossey undoubtedly had a large impact on the future of the mountain gorillas in Virunga National Park and may be the most important reason for their current survival. The latest census conducted on mountain gorillas in the Virungas showed that their numbers increased from about 260 individuals in Fossey's day to approximately 480 by 2010 (Dian Fossey Gorilla Fund International). This makes the mountain gorillas the only great ape population to show an increase in numbers in recent decades.

\section{The Future in Conservation}

In 1993, it was thought that approximately 300 mountain gorillas lived in the Volcanoes National Park (Roberts, 1993). In 1994, the Virunga National Park was placed on the List of World Heritage in Danger, as a result of the war in Rwanda and the massive influx of refugees from that country. This caused massive deforestation and poaching at the UNESCO site. Fortunately, the mountain gorillas were situated at a high enough altitude that they weren't directly affected, although the threat of resource depletion was very real (Virunga National Park). The gorillas still face a very real threat of extinction, resulting from poaching or being unintentionally caught in hunting traps. Poaching has influenced a number of species in Virunga National Park area. Today, you will not find any elephants in the Volcanoes National Park due to them being slain for the ivory in their tusks (Montgomery, 1991). The Karisoke Research Center is now sponsored by the Dian Fossey Gorilla Fund. Since Fossey's death, only one gorilla is said to have been killed due to poachers' snares in the park (Hayes, 1990). The patrols, sponsored by the foundations and funds previously discussed, are responsible for monitoring the health and safety of the gorillas and removing gorilla snares along with snares intended to capture other game, which have been responsible for causing fatal wounds to gorillas in the past. Karisoke today constitutes the only facility in the world 
from which long-term observations of gorillas in their natural habitat are carried out (Douglas, 1985).

\section{Conclusion}

Dian Fossey's aggressive stance directly conflicted with other conservationists' ideas of the time and even more greatly with ideas put forth today (Cara, 2007). Many believed that the Karisoke Park should have been used for education and tourism to spread the conservation initiative. In contrast to this ideology, during Fossey's stay, Karisoke became more closely relatable to an armed camp. Fossey was prepared to put any money that she gathered into anti-poaching missions and forget the research completely (Montgomery, 1991). As a result of her extreme actions toward poachers, she alienated most supporters, along with some in the Rwandan and United States governments. She was perfectly willing to violate human rights to protect the rights of animals (Nash \& Sutherland, 1991). Fossey's scientific method has been criticized by numerous individuals. It was said that her data collection did not follow the accepted protocol of using specific measurements for the group as a whole and was instead based almost entirely on individual gorillas' behaviours. It was suggested that Fossey failed to learn one of the most important rules of empirical science, which was the rule of separation (Montgomery, 1991). This separation refers to the distance that scientists would place between themselves and their study subjects. Fossey came to associate more closely with gorillas than she did with humans. Despite her drastic methods, much different from those exhibited by Goodall, Fossey was still successful in increasing conservation awareness of the mountain gorillas, and consequently of other subsequent endangered species. Jane Goodall remarked that, "Sometimes she [Fossey] was very stupid. But she brought the plight of the gorillas to everyone's attention" (Mckie, 2010). She may have been solely responsible for the protection of the mountain gorillas around Volcanoes National Park in Rwanda and by illuminating the severity of the issue, she made sure that later generations would continue her work. Her extreme dedication to the gorillas has been admired and praised by many, including myself. Dian Fossey was a woman determined to succeed in her quest for conservation and justice. Furthermore, Dian Fossey became a role model, even still today, and greatly helped to spur the conservation movement through her controversial 'active conservation'.

* Author: Brandy Rimmer is a student in the Bachelor of Science program at MacEwan University. 


\section{References}

Cara, E. (2007). An example of occupational coherence: The story of Dian Fossey, occupational therapist and primatologist. British Journal of Occupational Therapy. 70: 147-153.

Cawthon, L. (2005). Gorilla conservation. Primate Factsheets. Available from http://pin.primate.wisc.edu/factsheets/entry/gorilla/cons [Accessed 17 August 2013].

Dian Fossey Gorilla Fund International. Available from http://gorillafund.org/page.aspx?pid=769 [accessed 14 August 2013].

Douglas, C.A. (1985). Chimpanzee \& Gorilla Females: Oppressed? Off Our Backs: A Women's Newsjournal. 15(4): 14-15.

Dr. Birute Mary Galdikas Biography. (2011). Orangutan Foundation International. Available from http://www.orangutan.org/dr-galdikas-bio [accessed 13 November 2012].

Forth, S.S. (1994). Woman and the environment. NWSA J. 6(2): 324-329. doi: $10.2307 / 3031801$.

Fossey, Dian. (2008). Complete Dictionary of Scientific Biography. Available from http://www.encyclopedia.com/topic/Dian_Fossey.aspx [accessed 17 November 2012].

Fossey, D. (1983). Gorillas in the Mist. Houghton Mifflin, Boston, M.A.

Fossey, D. (1970). Making Friends with Mountain Gorillas. National Geographic. Available from http://ngm.nationalgeographic.com/2008/07/archive/fosseygorillas-1970/dian-fossey-text [accessed 12 November 2010].

Hayes, H. (1990). The Dark Romance of Dian Fossey. Simon and Schuster, New York City, N.Y.

Hinde, R. (1978). Primate studies and anthropology. Rain. 1-4.

Kahn, P., Koppel, T., Morell, V., \& Normile, D. (1993). Called 'trimates,' three bold women shaped their field. Science. 260(5106): 420.

doi:10.1126/science.260.5106.420.

Kanner, M. (2006). Going on instinct- gendering primatology in film. Journal of Popular Film and Television. 33(4): 206-212. doi:10.3200/JPFT.33.4.206-212. 
Karama, J. (2011). Developing an in situ conservation education program in Rwanda. International Zoo Educators J. 47: 46-51.

McKie, R. (2010). Chimps with everything: Jane Goodall's 50 years in the jungle. The Observer. Available from http://www.guardian.co.uk/science/2010/jun/27/janegoodall-chimps-africa-interview [accessed 13 November 2012].

Montgomery, S. (1991). Walking With the Great Apes: Jane Goodall, Dian Fossey, Birute Galdikas. Houghton Mifflin Co., Boston, M.A.

Mukanjari, S., Muchapondw, E., Zikhali, A., \& Bednar-Friedl, B. (2012). Evaluating the prospects of benefit sharing schemes in protecting mountain gorillas in central Africa. Environment for Development. 12-15.

Nash, J. E., and Sutherland, A. (1991). The moral elevation of animals: the case of "gorillas in the mist". International Journal of Politics, Culture, and Society. 5(1): 111-126. doi:10.1007/BF01390116.

Nielsen, H., and Spenceley, A. (2010). The success of tourism in Rwanda- tourism and more. Available from http://anna.spenceley.co.uk/files/publications/nature $\% 20 \mathrm{based} \% 20$ tourism/Touri

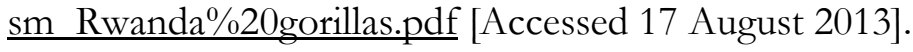

Roberts, J. (1993). Rwandan war threatens gorilla research project. Nature. 362(6415): 7. doi:10.1038/362007a0.

Virunga National Park. Available from http://whc.unesco.org/en/list/63 [accessed 17 November 2012]. 